Article

\title{
Protein Hydrolysates from Agricultural Crops-Bioactivity and Potential for Functional Food Development
}

\author{
Aoife L. McCarthy, Yvonne C. O'Callaghan and Nora M. O'Brien * \\ School of Food and Nutritional Sciences, University College Cork, Cork, Ireland; \\ E-Mails: 106502962@umail.ucc.ie (A.L.M.); y.ocallaghan@ucc.ie (Y.C.O’C.) \\ * Author to whom correspondence should be addressed; E-Mail: nob@ucc.ie; \\ Tel.: +353-21-4902884, Fax: +353-21-4270244.
}

Received: 4 November 2012; in revised form: 8 February 2013 / Accepted: 17 February 2013 / Published: 25 February 2013

\begin{abstract}
There has been an unprecedented demand for inexpensive plant-derived protein hydrolysates in recent years, owing to their potential nutritional applications. This review examines existing evidence regarding protein hydrolysates from agricultural crops such as wheat, soy, rapeseed, sunflower and barley. The bioactivity of these protein hydrolysates, including antioxidant and anti-inflammatory capabilities are discussed. In addition to evidence regarding their potential to enhance human nutrition, the effect of the hydrolysates on the techno-functional properties of foods will be reviewed.
\end{abstract}

Keywords: plant-derived; protein hydrolysates; bioactive; techno-functional

\section{Introduction}

Humans require a protein intake sufficient to maintain the body nitrogen balance and allow for desirable rates of deposition during growth and pregnancy. Ingestion of protein amounts greater than requirements results in the excess being metabolised and excreted. Conversely, in the case of inadequate dietary protein intake, the body utilizes its own proteins as a source of nitrogen; therefore a regular and sufficient intake is essential. Protein performs a number of key functions in the body including the building and repair of tissues, cell signalling and the provision of energy $(4 \mathrm{kcal} / \mathrm{g}$ protein). Proteins also perform enzymatic and structural functions.

Protein hydrolysates have been defined as "mixtures of polypeptides, oligopeptides and amino acids that are manufactured from protein sources using partial hydrolysis" [1]. There has been growing 
interest in these preparations over the last two decades, with novel bioactive peptides continually being discovered, as it has been shown that short-chain peptides from hydrolyzed proteins have a higher nutritive value and may be utilized more efficiently than an equivalent mixture of free amino acids [2]. Milk-based products are the source of the greatest number of bioactive peptides isolated to date. Other sources include meat, eggs and fish, in addition to plant sources such as soy and wheat [3]. Figure 1 illustrates the effect of bioactive peptides on major body systems. It has emerged that protein hydrolysates have many uses in human nutrition; ingredients in energy drinks, weight-control and sports nutrition products [4], sources of nutrition for elderly and immuno-compromised patients [5]. Clinical applications have also been suggested, including treatment of Phenylketonuria (PKU), liver disease, Crohn's disease and ulcerative colitis [6]. Other functions of plant-derived protein hydrolysates have been discussed in detail elsewhere [7]. These include use as natural herbicides, particularly corn gluten meal and soy and wheat hydrolysates [8] and as replacements for materials of bovine origin in fermentation media, to reduce risk of Bovine Spongiform Encephalopathy (BSE) contamination [9].

In recent years there has been an unprecedented demand by both consumers and industry, for inexpensive plant-derived proteins and bioactive peptides for human consumption. Additionally, alternative uses for co-products of the plant processing industry are highly sought. Such co-products include brewers' spent grain (BSG), wheat bran and okara (a soybean by-product of tofu production), which are excellent sources of both protein and fibre $[10,11]$.

The present review focuses on the bioactivity of protein hydrolysates from a range of agricultural crops, and their potential for inclusion into functional foods.

Figure 1. Physiological effects of food derived bioactive proteins on major body systems.

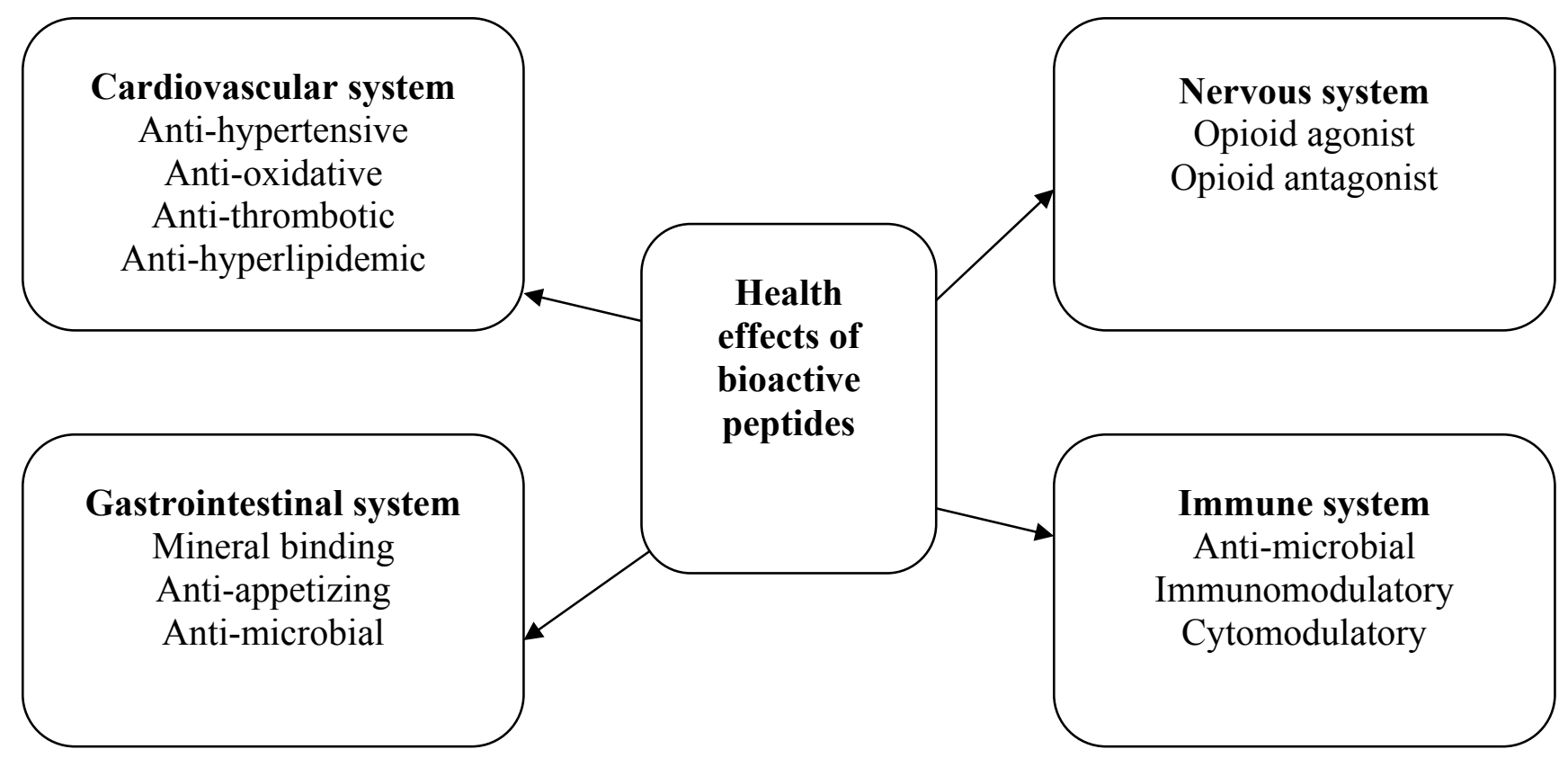




\section{Preparation of Protein Hydrolysates}

\subsection{Protein Hydrolysis}

Hydrolysis of proteins involves the cleavage of peptide bonds to give peptides of varying sizes and amino acid composition. There are a number of types of hydrolysis; enzymatic, acid or alkali hydrolysis. Chemical hydrolysis is difficult to control and reduces the nutritional quality of products [12], destroying L-form amino acids and producing toxic substances such as lysino-alanine [13]. Enzymatic hydrolysis works without destructing amino acids and by avoiding the extreme temperatures and $\mathrm{pH}$ levels required for chemical hydrolysis, the nutritional properties of the protein hydrolysates remain largely unaffected [12]. Production of protein hydrolysates in the food industry involves the use of digestive proteolytic enzymes from animals including chymotrypsin, trypsin and pepsin, or food grade enzymes obtained from plants and microorganisms which are regarded safe for human nutrition. Following protein hydrolysis, fractions can be categorised according to two characteristics. The first category consists of fractions with a high amino acid content. The second category consists of bioactive peptides with an amino acid sequence which is inactive in the intact protein molecule but becomes active in the hydrolysate following exposure to digestive and/or proteolytic enzymes [1]. It is worthy to note that the process of manufacturing protein hydrolysates has essentially remained the same since its emergence several decades ago and is still in its infancy [14]. Co-operation between manufacturers and end-users is necessary to develop optimum hydrolysates for specific functions [14].

\subsection{Post-Hydrolysis Treatment}

Following hydrolysis, the "crude hydrolysates" may undergo further processing. Commonly used post-hydrolysis processes include heat inactivation, ultrafiltration, hydrolysis by exoproteases and treatment with specific enzymes. Table 1 details the main post-hydrolysis processes and the function of each of these processes. Control of the molecular size of protein hydrolysates is an essential step in the development of protein hydrolysates for dietary use. Removal of high molecular weight proteins and peptides is primarily carried out using ultrafiltration. Protein hydrolysates can have a bitter taste and the elimination or reduction of this bitterness is essential to make the hydrolysates acceptable to consumers. The bitterness of protein hydrolysates is attribuatable to their hydrophobic amino acid content [1] and the release of these amino acids by exoproteases can reduce bitterness [15]. Post-hydrolysis processes can also be used to produce hydrolysates for the treatment of clinical conditions. For example, the use of phenylalanine ammonia lyase enzyme can reduce the phenylalanine content in protein hydrolysates, producing a hydrolysate suitable for patients with phenylketonuria, a disorder of phenylalanine metabolism [6]. 
Table 1. The main processes used following hydrolysis of protein (post-hydrolysis processes).

\begin{tabular}{cc}
\hline Process & Function \\
\hline Heat inactivation & Inactivation of proteolytic enzymes \\
Ultrafiltration & Removal of high molecular weight proteins \\
Use of specific enzymes & and peptides \\
Hydrolysis by exoproteases & Reduce content of specific amino acids \\
Activated carbon & Hydrolysis, reduction of bitterness \\
Absorption chromatography & Reduction of bitterness \\
\hline
\end{tabular}

\section{Bioactivity of Protein Hydrolysates}

\subsection{Antioxidant}

Protein hydrolysates from agricultural crops including soy, rapeseed, wheat, sunflower and barley have been investigated for their antioxidant potential. In 1980, it was reported that following proteolysis, soy protein hydrolysates showed antioxidant potential, as measured by the thiobarbituric (TBA) assay, which is a measure of lipid peroxidation. It was suggested that the release of bound antioxidant phenolics or copper chelating agents was responsible for the observed antioxidant activity [16]. Using similar methodology, Peña-Ramos and Xiong [17] provided comparable results. Soy protein hydrolysates prepared with Flavourzyme or chymotrypsin had antioxidant potential greater than unhydrolysed soy protein isolate. However, it was found that extensive degradation using enzymes such as papain unfavourably altered the antioxidant activity [17]. A further study measured the ability of these soy protein hydrolysates, prepared with Flavourzyme or chymotrypsin, to inhibit lipid oxidation in corked pork patties. However, in contrast to the initial study, the soy protein hydrolysates did not affect lipid oxidation by the TBA assay, but reduced conjugated diene (CD, a marker of free radicals) formation in stored pork patties [18]. CD is a secondary product of lipid oxidation. Later studies have also reported the antioxidant potential of soy protein hydrolysates [19-22]. Soy protein hydrolysates post-treated with ultrafiltration, resulting in low molecular weight fractions $(<10 \mathrm{kDa})$ have shown greatest antioxidant potential [20].

Protein hydrolysates from a range of other agricultural crops have been less extensively studied in comparison to soy hydrolysates. Rapeseed protein hydrolysates exhibited a dose-dependent inhibition of lipid peroxidation by a speculated proton donation mechanism [23]. Later studies supported these findings, with rapeseed hydrolysates showing the ability to act as reducing agents and scavenge hydroxyl radical and superoxide anion [24,25]. By employing the post-hydrolysis process of affinity chromatography, copper chelating peptides were isolated from sunflower protein hydrolysates. The ability to chelate copper increased mineral bioavailability and exerted antioxidant effects [26,27]. Protein hydrolysates isolated from wheat germ also possess radical scavenging abilities, with an antioxidant activity close to that of the well known, antioxidant $\alpha$-tocopherol. Interestingly, these hydrolysates had low molecular weight $<1500$ Da [28]. Similarly, enzymatic hydrolysates of buckwheat showed excellent antioxidant potential, scavenging (DPPH) radical, inhibiting linoleic acid peroxidation and possessing reducing power [29]. 
Protein hydrolysates isolated from co-products of the plant processing industry have also been investigated for antioxidant activity. While BSG protein isolate and associated hydrolysates do not possess antioxidant potential [30], okara hydrolysates protect against oxidation of linoleic acid [31]. Furthermore, it has been shown that fermentation of okara using Bacillus subtilis B2 can greatly improve its antioxidant activity, thus adding value to this co-product [32].

\subsection{Anti-hypertensive}

Normal blood pressure is in the range of 100-140 $\mathrm{mmHg}$ (systolic) and 60-90 mmHg (diastolic). Values greater than $140 \mathrm{mmHg}$ (systolic) and $90 \mathrm{mmHg}$ (diastolic) are classified as hypertension or high blood pressure. In hypertension, the blood pressure in the arteries is elevated and the heart has to work hard to pump blood around the body. According to the World Health Organisation, high blood pressure is particularly relevant in middle income European countries and African countries. A high percentage of stroke (51\%) and ischaemic heart disease $(45 \%)$ deaths worldwide are attributable to high systolic blood pressure [33]. Dietary and lifestyle changes, including a reduction in salt intake and an increase in physical activity levels, can positively influence blood pressure. However, in cases where such changes are ineffective or insufficient, drug treatments may be prescribed. Angiotensin-converting enzyme (ACE) inhibitors are an example of a drug treatment to control blood pressure. ACE reduces the conversion of angiotensin-1 (vasodilatory) to angiotensin-2 (vasoconstrictory) resulting in a reduced blood pressure. Hence, there is great interest in novel compounds that can inhibit ACE. In 2000, wheat germ hydrolysate and its dominant peptide significantly reduced mean arterial pressure (MAP) in spontaneously hypertensive rats. It was shown that the dominant bioactive peptide could be metabolised by an aminopeptidase to form an ACE inhibitory metabolite, indicating potential blood pressure lowering effects of the metabolite after absorption [34]. Similarly, a buckwheat protein hydrolysate was found to reduce systolic blood pressure in spontaneously hypertensive rats and also inhibit ACE, particularly when hydrolysis was carried out with pepsin followed by chymotrypsin and trypsin [35]. More recently, it was found that ultrasonic pre-treatment promotes the release of ACE inhibitory peptides during enzymatic proteolysis of wheat germ [36]. van der Ven et al. [37] described the processing conditions necessary to produce hydrolysates with maximal ACE inhibitory activity. It was suggested that the ACE inhibitory activity of protein hydrolysates is due to the synergistic action of the different peptides present, thus the isolation of peptides is not justified and optimising the entire peptide composition is essential. Response surface modelling (which comprises a body of methods to explore optimum operating conditions through experimental methods [38]) is effective in the optimisation of a number of parameters simultaneously to produce a hydrolysate with maximum ACE inhibitory activity. Similar to the results for antioxidant activity of protein hydrolysates, it was found that ACE inhibitory activity of soy protein hydrolysates increased with decreasing molecular weight of peptides; hence ACE inhibitory peptides have low molecular weight [39]. This study also focused on an important consideration for the formulation of anti-hypertensive functional foods, that is, the digestibility of the protein hydrolysates. Following in vitro gastric digestion, which simulates conditions in the human stomach, of the soy protein hydrolysates, the ACE inhibitory activity was retained. Stability during processing is another key factor and hydrolysates were shown to have sufficient stability to various heat $\left(20-100{ }^{\circ} \mathrm{C}\right)$ and $\mathrm{pH}(\mathrm{pH} 2-10)$ treatments. These findings were supported by a study published in 
2006, where it was also reported that soy protein hydrolysates possessed ACE inhibitory activity that was unaffected by in vitro gastrointestinal proteases [40]. Protein hydrolysates from a range of other crops including potato [41], corn [42,43], spinach [44], sunflower [45,46], peanut [47] and rapeseed [48] have exhibited high ACE inhibitory activities. Rice-bran, an under-utilized co-product of rice milling also has the potential to inhibit ACE activity, high molecular weight hydrolysates (10-50 and $>50 \mathrm{kDa}$ ) resulting in at least $50 \%$ inhibition [49]. In addition to ACE inhibition, there are a number of other potential mechanisms of inhibiting hypertension. These include activation of endothelial nitric oxide synthase (NOS), reduction of $\mathrm{Ca}^{2+}$ in vascular smooth muscle cells (VSMC) and rennin inhibition [50]. The ability of a compound to induce nitric oxide (NO) production via NOS and increase endothelial cell $\mathrm{Ca}^{2+}$ concentration contributes to vasodilation and reduced blood pressure [50]. Studies utilizing these mechanisms have also been carried out; for example soy protein isolate and hydrolysates have been shown to increase NO release in human aortic endothelial cells (HaoEC) [51].

\subsection{Cardiovascular Disease}

Cardiovascular diseases (CVD) are the primary cause of death globally, representing 30\% of all global deaths in 2008 [52]. Cardiovascular diseases are diseases of the heart and blood vessels and include coronary heart disease, cerebrovascular disease and peripheral arterial disease [52]. An unhealthy diet and physical inactivity are among the two main risk factors for CVD, resulting in raised blood pressure, blood lipids and blood glucose, overweight and obesity, which are classed as intermediate risk factors for CVD. The consumption of vegetable protein has been associated with a lower risk of coronary heart disease, in comparison to consumption of animal protein [53-55]. This observed effect may be attributed to decreases in serum cholesterol levels [56]. For more than 100 years, animal studies have shown the cholesterol lowering effect of soy protein compared with animal protein [57]. Reduced intestinal cholesterol absorption and increased faecal bile acid excretion, reduced levels of hepatic lipogenic enzymes such as glucose-6-phosphate dehydrogenase (G6PDH) and stimulation of adinopection, a cytokine involved in adipocyte differentiation and insulin sensitivity are all possible mechanisms for the lipid lowering effect of soy protein [58]. A meta-analysis of 38 studies indicated that soy protein consumption significantly decreased serum cholesterol, low density lipoprotein (LDL) cholesterol and triglyceride concentrations; there was also an increasing trend in high density lipoprotein (HDL) cholesterol concentrations [59]. An animal study carried out on genetically obese mice and dietary obese rats measured the effect of soy protein isolate and hydrolysate and on the rate of body fat disappearance. Feeding with either soy isolate or hydrolysate resulted in a significantly reduced body-fat content and plasma glucose levels in comparison with control, casein fed rodents. A decrease in the plasma total cholesterol level was also observed [60]. Soy hydrolysates have also demonstrated effects such as decreased cholesterol absorption both in vitro and in rats [61], anti-adipogenic in vitro [62], reduced fat mass and serum lipid in rats [63]. Sunflower hydrolysates produced using alcalase or pepsin inhibited the incorporation of cholesterol into bile salts micellar suspensions [64]. As mentioned in section 3.2 in vitro digestion did not decrease ACE inhibitory bioactivity of soy protein hydrolysates. It has also been shown that digestion of sunflower protein hydrolysates with simulated intestinal fluids produces new peptides that inhibit cholesterol incorporation into micellar suspensions [64]. Protein hydrolysates from crop processing co-products 
have been less extensively studied, but rice bran hydrolysates have demonstrated hypocholesterolemic activity, by reducing total cholesterol and increasing HDL cholesterol in male Wistar rats [65].

\subsection{Exercise and Performance Enhancement}

Muscle glycogen is an important fuel during periods of prolonged exercise and a relationship between increasing exercise intensity and a reliance on muscle glycogen is evident. Fatigue has been directly related to depleting glycogen stores [66-68]. Hence, the post-exercise glycogen synthesis rate is essential in determining the time required for recovery. It has been shown that carbohydrate and wheat protein hydrolysate combined with an amino acid mixture $(0.8 \mathrm{~g} / \mathrm{kg} / \mathrm{hr}$ and $0.4 \mathrm{~g} / \mathrm{kg} / \mathrm{hr}$, respectively), administered to cyclists for a five hour period post-exercise, increases glycogen synthesis rates compared to administration of carbohydrate alone [69]. Similarly, peak creatine kinase (CK) levels, as a result of initial muscle injury, were suppressed by wheat gluten hydrolysate in a dose-dependent manner in vivo [70]. Soy protein isolate is beneficial in muscle protein synthesis (MPS) following exercise. Consumption of the soy protein isolate was more effective than casein isolate but less effective than whey hydrolysate at increasing MPS both at rest and following resistance exercise [71]. Calbet and MacLean [72] suggested that carbohydrate and protein hydrolysates stimulate a synergistic insulin response, regardless of protein source. It was also found that the glucagon response depends on the increase in plasma amino acid composition, following protein solution ingestions and that pea and whey protein hydrolysates increased insulin to a greater extent and increased plasma amino acids more rapidly than cow's milk solution. It has been suggested that hydrolysates, particularly containing di- and tri-peptides, are absorbed more rapidly than either intact proteins or free form amino acids [73] which would support the use of protein hydrolysates for post-exercise recovery drinks as this would result in a greater increase in plasma amino acid concentration compared with the intact protein, over a two hour period [74]. The concentration of amino acids present in the blood regulates protein synthesis [75].

\subsection{Other Clinical Applications}

Protein hydrolysates represent an alternative to intact proteins and elemental (amino-acid based) formulas for the treatment of patients with various conditions. Phenylketonuria is a disorder of amino acid metabolism, specifically, absence or deficiency of phenylalanine hydroxylase for the conversion of phenylalanine to tyrosine. The lack of this enzyme results in phenylpyruvic acid accumulation in the blood which has intellectual and neurological implications if left untreated. Protein hydrolysates free of phenylalanine have been used for the treatment of phenylketonuric infants, with positive results on physical growth and mental development [76,77]. Hydrolysates suitable for the treatment of phenylketonuria have been prepared from animal proteins including casein [78] and whey [79]. Plant protein hydrolysates low in phenylalanine have been studied to a lesser extent; , however the potential of a low-phenylalanine soybean hydrolysate for dietetic purposes has been investigated [80]. In patients with chronic liver disease, complex alterations in the metabolism of proteins occurs and nutritional support is essential in the pathogenesis and treatment of this disease [6]. Patients with chronic liver failure have high plasma levels of aromatic amino acids (AAA) and methionine and low levels of branched-chain amino acids (BCAA) [81,82]. While casein hydrolysates are commonly used 
for nutritional applications in patients with chronic liver disease, a protein source with a higher level of BCAA is more desirable. Sunflower globulins have been suggested as excellent protein sources for the development of protein hydrolysates with high levels of BCAA [83]. Sunflower protein hydrolysate is recommended for enteral, parenteral and oral nutrition of liver disease patients, being hypoallergenic, having low bitterness and providing a high Fischer ratio (BCAA:AAA) of approximately 75 [84].

\subsection{Further Uses}

Advances in the understanding of protein hydrolysates have resulted in their use in biotechnology and fermentation. Hydrolysates have the ability to increase both production of monoclonal antibodies and productivity of therapeutic drugs produced by microorganisms and animal cells [7]. However, the most basic function of protein hydrolysates in biotechnology is as a source of nitrogen in industrial fermentation, cell culture and microbiological media [14]. As a protective mechanism against the spread of BSE from bovine animals to humans, plant materials have been recommended as an alternative for inclusion into fermentation media. Tryptone (a digest of casein) in Luria-Bertani broth supplies essential growth factors for Escherichia coli (E. coli). It has been shown that non-bovine and plant hydrolysates are efficient replacements for tryptone, measured by growth rate and growth yield of E. coli [9]. Furthermore, an animal-free cell culture medium supplement has been developed that can improve the bio-performance of the culture medium by providing peptides, carbohydrates, lipids, vitamins and minerals. [85]. Plant protein hydrolysates have also proved useful in the area of weed control. Corn gluten meal is commercially available as a natural pesticide, with corn gluten hydrolysate being suggested for similar results with easier application as a spray [86]. Corn, soybean and wheat protein hydrolysates have also been developed as herbicides [8].

\section{Techno-Functional Properties of Protein Hydrolysates}

\subsection{Solubility}

Solubility is the most important and generally the first techno-functional property examined during the development of new protein ingredients [87] due to its considerable effect on other techno-functional properties [88,89]. It has been proposed that reduction of the secondary structure of a protein and the enzymatic release of smaller polypeptide units are responsible for the increased solubility of hydrolysates compared to the original intact protein [90,91]. The solubility of a number of protein hydrolysates from agricultural crops has been studied. Barley protein hydrolysates showed highest solubility at strongly basic $(\mathrm{pH} 10-\mathrm{pH} 12)$ conditions [92]. Similarly, Claver et al. [93] found that the solubility of wheat protein hydrolysates was strongly influenced by $\mathrm{pH}$, with lowest and highest solubility at $\mathrm{pH} 4$ and 6, respectively. The use of rapeseed and other oilseed protein isolates is restricted due to their low solubility, which is a result of protein denaturation during industrial oil extraction [94]. To improve solubility and functionality, protein isolates from oilseeds can be hydrolysed. It has been found that rapeseed hydrolysates exhibit $>90 \%$ solubility at pH 5-9 [95]. Soy protein hydrolysates were found to be almost completely soluble ( $>99 \%)$ in the range of $\mathrm{pH} 2-9$, whereas the intact protein had highest solubility at pH 9 [96]. Tsumara et al. [97] also demonstrated that the solubility of soy protein hydrolysates was $\mathrm{pH}$-dependent. The production of hydrolysates that 
are soluble at acidic $\mathrm{pH}$ is essential for the supplementation of fruit juices and acidic drinks [6,98]. In contrast to soy protein hydrolysates, okara protein isolates showed highest solubility at $\mathrm{pH} 12$, with acid modified isolates enhancing solubility, thus increasing potential applications of okara protein as a food ingredient [99]. Chan and Ma [99] suggested that the low solubility of okara (a by-product of soymilk manufacture) hydrolysates compared to soy hydrolysates is due to protein denaturation caused by severe heat treatments during soymilk manufacture.

\subsection{Emulsifying Properties}

The ability of proteins to interact with lipids and form stable emulsions is essential to yield a stable food product. Rapeseed protein hydrolysates have higher emulsifying activity (at least $20 \%$ greater) and stability than rapeseed protein isolates [94]. Enzymatic hydrolysates of soy protein resulted in an increased emulsification activity [100]. Studies examining protein hydrolysates from different crop sources suggest that the emulsifying capacity of the hydrolysates is related to the degree of hydrolysis, with a low degree of hydrolysis $(3 \%-5 \%)$ increasing and a high degree of hydrolysis $(\sim 8 \%)$ decreasing emulsifying capacity $[94,101,102]$. Ultrafiltered rapeseed protein hydrolysate was demonstrated to have greater emulsification stability compared to that of whole egg [95] and wheat germ protein hydrolysates had higher emulsification capacity, activity and stability than bovine casein [91]. It is generally accepted that limited hydrolysis improves the emulsification properties of proteins by exposing hydrophobic amino acid residues (which may interact with oil), while the hydrophilic residues interact with water [94]. Similarly, an increase in hydrophilicity as a result of acid modification has been shown to increase the emulsification activity index (EAI) of okara protein isolates [99].

\subsection{Foaming}

Foaming is of special interest in the food industry as it provides a desirable and unique texture to a range of aerated foods and beverages including ice-cream, bread, cakes, meringues, champagne and beer. It is essential that food foams are stable for consumer acceptability, since consumer perception of quality is influenced by appearance. Wheat germ has been shown to have poor foaming properties [103]. However enzymatic treatment of wheat germ increases foam volume/height but decreases foam stability. The trend of increased foam volume being coupled with decreased foam stability has been reported in previous studies on rice bran protein hydrolysate and acid modification of okara protein hydrolysate $[99,104]$. The absence of large protein components, which function to stabilise the foam, may contribute to the observed lack of foam stability [93]. In a similar study of wheat germ hydrolysates it was found that foaming capacity was increased at a degree of hydrolysis (DH) of $5 \%$, resulting in a $74 \%$ increase in foam volume compared to the control. The foam was also most stable at DH of $5 \%$, with $40 \%$ of foam volume sustained after 60 minutes. There was an inverse relationship between $\mathrm{DH}$ and foam stability, with stability in the order of $\mathrm{DH} 5 \%>$ DH $10 \%>$ DH 15\%. Similar to suggestions by Claver et al. [93], the stability of the foams was attributed to the presence of larger component proteins and a partial hydrolysis, whereas a higher $\mathrm{DH}$ increases the number of polypeptide chains which do not have the ability to stabilise foams [102]. The study of both soy [97] and rapeseed [94] protein hydrolysates produced comparable results. Regarding 
the effect of $\mathrm{pH}$ on foaming, barley hydrolysates had greater foam stability at basic $\mathrm{pH}$ values and very low stability at acidic $\mathrm{pH}$ [105].

\subsection{Gelation}

The ability to manipulate the gel formation properties of a substance is important since gelation is desirable for the bakery and meat industries, but not for foods such as beverages and frozen deserts [106]. As a food ingredient, gelation is one of the most important techno-functional properties of soy protein, however soy protein hydrolysates possess poor gel-forming ability [107]. Transglutaminase (TGase) is a polymeriser shown to be effective in improving gelling of proteins [108], which improved the gelling ability of soy protein hydrolysates [107,109] but the gels formed were inferior to the starting soy protein/isolate in terms of gel strength. It has been suggested that the reduced ability to form gels may be due to lower surface hydrophobicity and short peptide chain length of the hydrolysates [109]. Research has been carried out with a focus on manipulating conditions to give desired gelation properties. For example, it has been shown that sodium chloride $(\mathrm{NaCl})$ concentrations greater than $0.2 \mathrm{M}$ can accelerate gelation by sunflower protein hydrolysates but result in a gel of lower strength [110]. Addition of a polysaccharide such as guar gum can enhance the gel strength of canola protein isolates [111] and protein concentration and $\mathrm{pH}$ have been identified as important factors influencing gel formation by canola protein isolate coupled with guar gum [112]. Hence, while the gel forming ability of protein hydrolysates from agricultural crops is not as strong as that from proteins, processes are available to improve gelation where necessary.

\section{Safety of Protein Hydrolysates}

The use of dietary proteins and protein hydrolysates in food products is generally allowed in European countries and has the status of "generally regarded as safe" (GRAS) in the United States of America [113]. In Europe, novel foods are defined as foods and food ingredients that have not been used for human consumption to a significant degree within the European Community before 15 May 1997 [114]. Safety evaluation by external independent experts and approval by competent authorities is necessary before a novel product is allowed on the market. Schaafsma [1] proposed a decision tree that should be used for determining the proposed safety assessment of protein hydrolysates and fractions thereof. Factors for consideration in deciding if a protein hydrolysate should follow procedure for novel foods include documented history of safe use, acceptable food grade hydrolysis process and the effect of intake on amino acid levels [1]. Hydrolysed proteins have a long history of safe use, but it is important to note that the majority of studies in this area look at animal-derived protein hydrolysates in infant feeding practices [114-117]. Some evidence has been produced regarding the sub-chronic toxicity of plant protein hydrolysates. Consumption of potato protein isolates is "well tolerated and without adverse effect" in Wistar rats, with parameters including body weight, body weight gain, mortality and organ weight remaining unchanged [118]. Protein isolates from canola have also been reported to be safe, following a 13 week consumption trial in rats, being practically devoid of natural toxicants and environmental contaminants. The canola protein isolates had no effect on body weight, food consumption, clinical observations, motor activity or ophthalmic examinations [119]. One particular consideration for the safety of protein hydrolysates and bioactive 
peptides is their allergenicity. Most allergenic substances are protein-based compounds [120] and peptides in the range of 800-1500 Da are considered non-allergenic [5]. While hydrolysis breaks down proteins into low molecular weight peptides thus lessening the allergenic properties [121], some hydrolysates may retain their parent protein allergenic effects [122]. Therefore, there is a need to further investigate the safety of plant-derived protein hydrolysates and bioactive peptides.

\section{Conclusions}

Protein hydrolysates derived from agricultural crops have exhibited antioxidant and ACE inhibitory potential, with low molecular weight fractions demonstrating greatest effects. There is substantial evidence which supports the ability of soy protein hydrolysates to reduce CVD risk however hydrolysates obtained from other plant sources require further investigation. Protein hydrolysates show greater potential than intact protein to increase muscle glycogen and muscle protein synthesis and have also demonstrated potential in the treatment of clinical conditions, particularly sunflower hydrolysates which may be used in cases of chronic liver disease. In terms of techno-functional properties, hydrolysates with a low DH have desirable effects on emulsification, foaming and solubility properties. To conclude, protein hydrolysates from agricultural crops have demonstrated favourable bioactive and techno-functional properties that could be exploited for the development of functional foods. For neutraceutical development, clinical trials are necessary to confirm biological activity and safety, in addition to addressing issues such as stability during food processing, organoleptic issues and identifying the fate of plant-derived hydrolysates during passage through the gastrointestinal tract. Furthermore, protein hydrolysates from co-products of the plant processing industry should be investigated for their potential bioactive and techno-functional properties.

\section{Acknowledgements}

Funding for this research was provided under the National Development Plan, through the Food Institutional Research Measure, administered by the Department of Agriculture, Food and the Marine, Ireland.

\section{References}

1. Schaafsma, G. Safety of protein hydrolysates, fractions thereof and bioactive peptides in human nutrition. Eur. J. Clin. Nutr. 2009, 63, 1161-1168.

2. Grimble, G.; Keohane, P.; Higgins, B.; Kaminski, M., Jr.; Silk, D. Effect of peptide chain length on amino acid and nitrogen absorption from two lactalbumin hydrolysates in the normal human jejunum. Clin. Sci. 1986, 71, 65-69.

3. Hartmann, R.; Meisel, H. Food-derived peptides with biological activity: From research to food applications. Curr. Opin. Biotech. 2007, 18, 163-169.

4. Frokjaer, S. Use of hydrolysates for protein supplementation. Food Technol. 1994, 48, 86-88.

5. Nagodawithana, T.W.; Nelles, L.; Trivedi, N.B. Protein hydrolysates as hypoallergenic, flavors and pallatants for companion animals. In Protein Hydrolysates in Biotechnology; Pasupuleti, V.K., Demain, A.L., Eds.; Springer Dordrecht Heidelberg: New York, NY, USA, 2010; pp. 191-207. 
6. Clemente, A. Enzymatic protein hydrolysates in human nutrition. Trends Food Sci. Tech. 2000, 11, 254-262.

7. Pasupuleti, V.K.; Holmes, C.; Demain, A.L. Applications of protein hydrolysates in biotechnology. In Protein Hydrolysates in Biotechnology; Pasupuleti, V.K., Demain, A.L., Eds.; Springer Dordrecht Heidelberg: New York, NY, USA, 2010; pp. 1-9.

8. Christians, N.E.; Garbutt, J.T.; Liu, D. Preemergence Weed Control Using Plant Protein Hydrolysate. U.S. patent 5,290,749, 1 March 1994.

9. Ranganathan, Y.; Patel, S.; Pasupuleti, V.K.; Meganathan, R. Protein hydrolysates from non-bovine and plant sources replaces tryptone in microbiological media. In Protein Hydrolysates in Biotechnology; Pasupuleti, V.K., Demain, A.L., Eds.; Springer Dordrecht Heidelberg: New York, NY, USA, 2010; pp. 115-125.

10. Mandalari, G.; Faulds, C.B.; Sancho, A.I.; Saija, A.; Bisignano, G.; LoCurto, R.; Waldron, K.W. Fractionation and characterisation of arabinoxylans from brewers' spent grain and wheat bran. $J$. Cereal Sci. 2005, 42, 205-212.

11. O'Toole, D.K. Characteristics and use of okara, the soybean residue from soy milk production a review. J. Agric. Food Chem. 1999, 47, 363-371.

12. Celus, I.; Brijs, K.; Delcour, J.A. Enzymatic hydrolysis of brewers' spent grain proteins and technofunctional properties of the resulting hydrolysates. J. Agric. Food Chem. 2007, 55, 8703-8710.

13. Lahl, W.J.; Grindstaff, D.A. Spices and seasonings: Hydrolyzed proteins. In Proceedings of the 6th SIFST Symposium on Food Ingredients-Applications, Status and Safety, Singapore Institute of Food Science and Technology, Singapore, 27-29 April 1989; pp. 51-65.

14. Pasupuleti, V.K.; Braun, S. State of the art manufacturing of protein hydrolysates. In Protein Hydrolysates in Biotechnology; Pasupuleti, V.K., Demain, A.L., Eds.; Springer Dordrecht Heidelberg: New York, NY, USA, 2010; pp. 11-32.

15. Pedersen, B. Removing bitterness from protein hydrolysates. Food Technol. 1994, 48, 96-98.

16. Yee, J.; Shipe, W.; Kinsella, J. Antioxidant effects of soy protein hydrolysates on copper catalyzed methyl linoleate oxidation. J. Food Sci. 1980, 45, 1082-1083.

17. Peña-Ramos, E.A.; Xiong, Y. Antioxidant activity of soy protein hydrolysates in a liposomal system. J. Food Sci. 2002, 67, 2952-2956.

18. Peña-Ramos, E.A.; Xiong, Y.L. Whey and soy protein hydrolysates inhibit lipid oxidation in cooked pork patties. Meat Sci. 2003, 64, 259-263.

19. Fan, J.; Saito, M.; Yanyan, Z.; Szesze, T.; Wang, L.; Tatusmi, E.; Li, L. Gel-forming ability and radical-scavenging activity of soy protein hydrolysate treated with transglutaminase. J. Food Sci. 2005, 70, C87-C92.

20. Moure, A.; Dominguez, H.; Parajo, J.C. Antioxidant properties of ultrafiltration-recovered soy protein fractions from industrial effluents and their hydrolysates. Process. Biochem. 2006, 41, $447-456$.

21. Xin, W.; LianZhou, J.; Xia, W.; RuiHong, T. Study on alkaline protease hydrolysis of soy protein isolate and its antioxidant activity. Dongbei Nongye Daxue Xuebao 2011, 42, 24-31. 
22. Roblet, C.; Amiot, J.; Lavigne, C.; Marette, A.; Lessard, M.; Jean, J.; Ramassamy, C.; Moresoli, C.; Bazinet, L. Screening of in vitro bioactivities of a soy protein hydrolysate separated by hollow fiber and spiral-wound ultrafiltration membranes. Food Res. Int. 2012, 46, 237-249.

23. Zhang, S.B.; Wang, Z.; Xu, S.Y. Antioxidant and antithrombotic activities of rapeseed peptides. J. Am. Oil Chem. Soc. 2008, 85, 521-527.

24. Xue, Z.; Yu, W.; Liu, Z.; Wu, M.; Kou, X.; Wang, J. Preparation and antioxidative properties of a rapeseed (Brassica napus) protein hydrolysate and three peptide fractions. J. Agric. Food Chem. 2009, 57, 5287-5293.

25. Pan, M.; Jiang, T.S.; Pan, J.L. Antioxidant activities of rapeseed protein hydrolysates. Food Bioprocess. Tech. 2011, 4, 1144-1152.

26. Megías, C.; Pedroche, J.; Yust, M.M.; Girón-Calle, J.; Alaiz, M.; Millán, F.; Vioque, J. Affinity purification of copper-chelating peptides from sunflower protein hydrolysates. J. Agric. Food Chem. 2007, 55, 6509-6514.

27. Megías, C.; Pedroche, J.; Yust, M.M.; Girón-Calle, J.; Alaiz, M.; Millán, F.; Vioque, J. Production of copper-chelating peptides after hydrolysis of sunflower proteins with pepsin and pancreatin. LWT Food Sci. Technol. 2008, 41, 1973-1977.

28. Zhu, K.; Zhou, H.; Qian, H. Antioxidant and free radical-scavenging activities of wheat germ protein hydrolysates (WGPH) prepared with alcalase. Process. Biochem. 2006, 41, 1296-1302.

29. Tang, C.H.; Peng, J.; Zhen, D.W.; Chen, Z. Physicochemical and antioxidant properties of buckwheat (Fagopyrum esculentum Moench) protein hydrolysates. Food Chem. 2009, 115, 672-678.

30. McCarthy, A.L.; O’Callaghan, Y.C.; Connolly, A.; Piggott, C.O.; FitzGerald, R.J.; O’Brien, N.M. In vitro antioxidant and anti-inflammatory effects of brewers' spent grain protein rich isolate and its associated hydrolysates. Food Res. Int. 2013, 50, 205-212.

31. Yokomizo, A.; Takenaka, Y.; Takenaka, T. Antioxidative activity of peptides prepared from okara protein. Food Sci. Technol. Res. 2002, 8, 357-359.

32. Zhu, Y.; Fan, J.; Cheng, Y.; Li, L. Improvement of the antioxidant activity of Chinese traditional fermented okara (Meitauza) using Bacillus subtilis B2. Food Control. 2008, 19, 654-661.

33. World Health Organisation 2009, Global Health Risks: Mortality and Burden of Disease Attributable to Selected Major Risks. Available online: http://www.who.int/healthinfo/global_ burden_disease/GlobalHealthRisks_report_full.pdf (accessed on 2 July 2012).

34. Matsui, T.; ChunHui, L.; Tanaka, T.; Maki, T.; Osajima, Y.; Matsumoto, K. Depressor effect of wheat germ hydrolysate and its novel angiotensin I-converting enzyme inhibitory peptide, Ile-Val-Tyr, and the metabolism in rat and human plasma. Biol. Pharmaceut. Bull. 2000, 23, $427-431$.

35. Li, C.H.; Matsui, T.; Matsumoto, K.; Yamasaki, R.; Kawasaki, T. Latent production of angiotensin I-converting enzyme inhibitors from buckwheat protein. J. Pept. Sci. 2002, 8, 267-274.

36. Jia, J.; Ma, H.; Zhao, W.; Wang, Z.; Tian, W.; Luo, L.; He, R. The use of ultrasound for enzymatic preparation of ACE-inhibitory peptides from wheat germ protein. Food Chem. 2010, $119,336-342$. 
37. Van der Ven, C.; Gruppen, H.; de Bont, D.; Voragen, A.G.J. Optimisation of the angiotensin converting enzyme inhibition by whey protein hydrolysates using response surface methodology. Int. Dairy J. 2002, 12, 813-820.

38. Lenth, R.V. Response-Surface Methods in R, using rsm. J. Stat. Softw. 2009, 32, 1-17.

39. Wu, J.; Ding, X. Characterization of inhibition and stability of soy-protein-derived angiotensin I-converting enzyme inhibitory peptides. Food Res. Int. 2002, 35, 367-375.

40. Chiang, W.D.; Tsou, M.J.; Tsai, Z.Y.; Tsai, T.C. Angiotensin I-converting enzyme inhibitor derived from soy protein hydrolysate and produced by using membrane reactor. Food Chem. 2006, 98, 725-732.

41. Pihlanto, A.; Akkanen, S.; Korhonen, H.J. ACE-inhibitory and antioxidant properties of potato (Solanum tuberosum). Food Chem. 2008, 109, 104-112.

42. Suh, H.; Whang, J.; Lee, H. A peptide from corn gluten hydrolysate that is inhibitory toward angiotensin I converting enzyme. Biotechnol. Lett. 1999, 21, 1055-1058.

43. Kim, J.; Whang, J.; Kim, K.; Koh, J.; Suh, H. Preparation of corn gluten hydrolysate with angiotensin I converting enzyme inhibitory activity and its solubility and moisture sorption. Process. Biochem. 2004, 39, 989-994.

44. Yang, Y.; Marczak, E.D.; Yokoo, M.; Usui, H.; Yoshikawa, M. Isolation and antihypertensive effect of angiotensin I-converting enzyme (ACE) inhibitory peptides from spinach Rubisco. $J$. Agric. Food Chem. 2003, 51, 4897-4902.

45. Megías, C.; del Mar Yust, M.; Pedroche, J.; Lquari, H.; Girón-Calle, J.; Alaiz, M.; Millán, F.; Vioque, J. Purification of an ACE inhibitory peptide after hydrolysis of sunflower (Helianthus annuus L.) protein isolates. J. Agric. Food Chem. 2004, 52, 1928-1932.

46. Megías, C.; Pedroche, J.; Yust, M.M.; Alaiz, M.; Girón-Calle, J.; Millán, F.; Vioque, J. Purification of angiotensin converting enzyme inhibitory peptides from sunflower protein hydrolysates by reverse-phase chromatography following affinity purification. LWT Food Sci. Technol. 2009, 42, 228-232.

47. Jamdar, S.; Rajalakshmi, V.; Pednekar, M.; Juan, F.; Yardi, V.; Sharma, A. Influence of degree of hydrolysis on functional properties, antioxidant activity and ACE inhibitory activity of peanut protein hydrolysate. Food Chem. 2010, 121, 178-184.

48. Yoshie-Stark, Y.; Wada, Y.; Schott, M.; Wäsche, A. Functional and bioactive properties of rapeseed protein concentrates and sensory analysis of food application with rapeseed protein concentrates. LWT Food Sci. Technol. 2006, 39, 503-512.

49. Hull, J.N.; Kannan, A.; Hettiarachchy, N.S. Antioxidant and antihypertensive activities of rice bran peptides. Discovery Student J. Dale Bumpers College Agric. Food Life Sci. 2011, 11, 52-57.

50. Chen, Z.Y.; Peng, C.; Jiao, R.; Wong, Y.M.; Yang, N.; Huang, Y. Anti-hypertensive nutraceuticals and functional foods. J. Agric. Food Chem. 2009, 57, 4485-4499.

51. Ringseis, R.; Matthes, B.; Lehmann, V.; Becker, K.; Schöps, R.; Ulbrich-Hofmann, R.; Eder, K. Peptides and hydrolysates from casein and soy protein modulate the release of vasoactive substances from human aortic endothelial cells. BBA Gen. Subj. 2005, 1721, 89-97.

52. World Health Organisation 2011. Available online: http://www.who.int/mediacentre/factsheets/ fs317/en/index.html (accessed on 2 July 2012). 
53. Hilleboe, H.E. Some epidemiologic aspects of coronary artery disease. J. Chronic Dis. 1957, 6, 210-228.

54. Terpstra, A.H.; Hermus, R.J. West CE. The role of dietary protein in cholesterol metabolism. World Rev. Nutr. Diet. 1983, 42, 1-55.

55. Clifton, P.M. Protein and coronary heart disease: The role of different protein sources. Curr. Atheroscler. Rep. 2011, 13, 493-498.

56. Manson, J.E.; Tosteson, H.; Ridker, P.M.; Satterfield, S.; Hebert, P.; O'Connor, G.T.; Buring, J.E.; Hennekens, C.H. The primary prevention of myocardial infarction. N. Engl. J. Med. 1992, 326, 1406-1416.

57. Ignatowsky, M.A. Influence de la nourriture animale sur l'organisme des lapins. Arch. Med. Exp. Anat. Pathol. 1908, 20, 1-20.

58. Velasquez, M.T.; Bhathena, S.J. Role of dietary soy protein in obesity. Int. J. Med. Sci. 2007, 4, 72-82.

59. Anderson, J.W.; Johnstone, B.M.; Cook-Newell, M.E. Meta-analysis of the effects of soy protein intake on serum lipids. N. Engl. J. Med. 1995, 333, 276-282.

60. Aoyama, T.; Fukui, K.; Takamatsu, K.; Hashimoto, Y.; Yamamoto, T. Soy protein isolate and its hydrolysate reduce body fat of dietary obese rats and genetically obese mice (yellow KK). Nutrition 2000, 16, 349-354.

61. Nagaoka, S.; Miwa, K.; Eto, M.; Kuzuya, Y.; Hori, G.; Yamamoto, K. Soy protein peptic hydrolysate with bound phospholipids decreases micellar solubility and cholesterol absorption in rats and Caco-2 cells. J. Nutr. 1999, 129, 1725-1730.

62. Tsou, M.J.; Kao, F.J.; Tseng, C.K.; Chiang, W.D. Enhancing the anti-adipogenic activity of soy protein by limited hydrolysis with Flavourzyme and ultrafiltration. Food Chem. 2010, 122, 243-248.

63. Park, J.H.; Park, M.N.; Lee, I.S.; Kim, Y.K.; Kim, W.S.; Lee, Y.S. Effects of soy protein, its hydrolysate and peptide fraction on lipid metabolism and appetite-related hormones in rats. Korean J. Nutr. 2010, 43, 342-350.

64. Megías, C.; Pedroche, J.; del Mar Yust, M.; Alaiz, M.; Girón-Calle, J.; Millán, F.; Vioque, J. Sunflower protein hydrolysates reduce cholesterol micellar solubility. Plant. Food Hum. Nutr. 2009, 64, 86-93.

65. Revilla, E.; Maria, C.S.; Miramontes, E.; Bautista, J.; García-Martínez, A.; Cremades, O.; Cert, R.; Parrado, J. Nutraceutical composition, antioxidant activity and hypocholesterolemic effect of a water-soluble enzymatic extract from rice bran. Food Res. Int. 2009, 42, 387-393.

66. Bergström, J.; Hultman, E. Muscle glycogen synthesis after exercise: An enhancing factor localized to the muscle cells in man. Nature 1966, 210, 309-310.

67. Bergström, J.; Hultman, E. A study of the glycogen metabolism during exercise in man. Scand. J. Clin. Lab. Inv. 1967, 19, 218-228.

68. Bergström, J.; Hermansen, L.; Hultman, E.; Saltin, B. Diet, muscle glycogen and physical performance. Acta. Physiol. Scand. 1967, 71, 140-150.

69. Van Loon, L.J.C.; Saris, W.H.M.; Kruijshoop, M.; Wagenmakers, A.J.M. Maximizing postexercise muscle glycogen synthesis: Carbohydrate supplementation and the application of amino acid or protein hydrolysate mixtures. Am. J. Clin. Nutr. 2000, 72, 106-111. 
70. Koikawa, N.; Nakamura, A.; Ngaoka, I.; Aoki, K.; Sawaki, K.; Suzuki, Y. Delayed-onset muscle injury and its modification by wheat gluten hydrolysate. Nutrition 2009, 25, 493-498.

71. Tang, J.E.; Moore, D.R.; Kujbida, G.W.; Tarnopolsky, M.A.; Phillips, S.M. Ingestion of whey hydrolysate, casein, or soy protein isolate: Effects on mixed muscle protein synthesis at rest and following resistance exercise in young men. J. Appl. Physiol. 2009, 107, 987-992.

72. Calbet, J.A.L.; MacLean, D.A. Plasma glucagon and insulin responses depend on the rate of appearance of amino acids after ingestion of different protein solutions in humans. J. Nutr. 2002, 132, 2174-2182.

73. Di Pasquale, M.G. Amino Acids and Proteins for the Athlete: The Anabolic Edge; CRC Press: Boca Raton, FL, USA, 1997.

74. Van Loon, L.J.C.; Saris, W.H.M.; Verhagen, H.; Wagenmakers, A.J.M. Plasma insulin responses after ingestion of different amino acid or protein mixtures with carbohydrate. Am. J. Clin. Nutr. 2000, 72, 96-105.

75. Bohé, J.; Low, A.; Wolfe, R.R.; Rennie, M.J. Human muscle protein synthesis is modulated by extracellular, not intramuscular amino acid availability: A dose-response study. J. Physiol. 2003, 552, 315-324.

76. Berry, H.; Sutherland, B.; Hunt, M.; Fogelson, M.; O’Grady, D. Treatment of children with phenylketonuria using a phenylalanine-free protein hydrolysate (Albumaid XP). Am. J. Clin. Nutr. 1976, 29, 351-357.

77. Acosta, P.B.; Yannicelli, S.; Marriage, B.; Mantia, C.; Gaffield, B.; Porterfield, M.; Hunt, M.; McMaster, N.; Bernstein, L.; Parton, P. Nutrient intake and growth of infants with phenylketonuria undergoing therapy. J. Pediatr. Gastr. Nutr. 1998, 27, 287-291.

78. Bickel, H.; Gerrard, J.; Hickmans, E.M. The influence of phenylalanine intake on the chemistry and behaviour of a phenylketonuria child. Acta. Paediatr. 1954, 43, 64-77.

79. Delvivo, F.M.; Vieira, C.R.; Biasutti, E.A.R.; Capobiango, M.; Silva, V.D.M.; Afonso, W.O.; Silvestre, M.P.C. Effect of adsorption medium, hydrolytic parameters and ultrafiltration on the phenylalanine removal from pancreatic whey hydrolysates. Am. J. Food Technol. 2006, 1, 94-104.

80. Yamashita, M.; Arai, S.; Fujimaki, M. A low-phenylalanine high-tyrosine plastein as an acceptable dietetic food. Method of preparation by use of enzymatic protein hydrolysis and resynthesis. J. Food Sci. 1976, 41, 1029-1032.

81. Morgan, M.Y.; Marshall, A.; Milsom, J.P.; Sherlock, S. Plasma amino-acid patterns in liver disease. Gut 1982, 23, 362-370.

82. Schenker, S.; Beer, W.H. Nutrients in the pathogenesis and treatment of hepatic encephalopathy. In Nutrition and the Origins of Disease; Halsted, C.H., Rucker, B.B., Eds.; Academic Press: London, UK, 1989; pp. 285-307.

83. Bautista, J.; Hernandez-Pinzon, I.; Alaiz, M.; Parrado, J.; Millan, F. Low molecular weight sunflower protein hydrolysate with low concentration in aromatic amino acids. J. Agric. Food Chem. 1996, 44, 967-971.

84. Bautista, J.; Corpas, R.; Cremades, O.; Hernández-Pinzón, I.; Ramos, R.; Villanueva, A.; Sánchez-Vioque, R.; Clemente, A.; Pedroche, J.; Vioque, J. Sunflower protein hydrolysates for dietary treatment of patients with liver failure. J. Am. Oil Chem. Soc. 2000, 77, 121-126. 
85. Siemensma, A.; Babcock, J.; Wilcox, C.; Huttinga, H. Towards an understanding of how protein hydrolysates stimulate more efficient biosynthesis in cultured cells. In Protein Hydrolysates in Biotechnology; Pasupuleti, V.K., Demain, A.L., Eds.; Springer Dordrecht Heidelberg: New York, NY, USA, 2010; pp. 33-54.

86. Christians, N.; Liu, D.; Unrah, J.B. The use of protein hydrolysates for weed control. In Protein Hydrolysates in Biotechnology; Pasupuleti, V.K., Demain, A.L., Eds.; Springer Dordrecht Heidelberg: New York, NY, USA, 2010; pp. 127-133.

87. Zayas, J.F. Functionality of Proteins in Foods; Springer-Verlag: Berlin, Germany, 1997; p. 6.

88. Kinsella, J.E.; Melachouris, N. Functional properties of proteins in foods: A survey. Crit. Rev. Food Sci. 1976, 7, 219-280.

89. Vojdani, F. Solubility. In Methods of Testing Protein Functionality; Hall, G.M., Ed.; Blackie Academic \& Professional: London, UK, 1996; pp. 11-60.

90. Adler-Nissen, J. Enzymatic Hydrolysis of Food Proteins; Elsevier Applied Science Publishers: London, UK, 1986; pp. 122-124.

91. Chobert, J.M.; Bertrand-Harb, C.; Nicolas, M.G. Solubility and emulsifying properties of caseins and whey proteins modified enzymically by trypsin. J. Agric. Food Chem. 1988, 36, 883-892.

92. Yalcin, E.; Celik, S. Solubility properties of barley flour, protein isolates and hydrolysates. Food Chem. 2007, 104, 1641-1647.

93. Claver, I.P.; Zhou, H. Enzymatic hydrolysis of defatted wheat germ by proteases and the effect on the functional properties of resulting protein hydrolysates. J. Food Biochem. 2005, 29, 13-26.

94. Vioque, J.; Sánchez-Vioque, R.; Clemente, A.; Pedroche, J.; Millán, F. Partially hydrolyzed rapeseed protein isolates with improved functional properties. J. Am. Oil Chem. Soc. 2000, 77, 447-450.

95. Yoshie-Stark, Y.; Wada, Y.; Wäsche, A. Chemical composition, functional properties, and bioactivities of rapeseed protein isolates. Food Chem. 2008, 107, 32-39.

96. Chiang, W.D.; Shih, C.J.; Chu, Y.H. Functional properties of soy protein hydrolysate produced from a continuous membrane reactor system. Food Chem. 1999, 65, 189-194.

97. Tsumura, K.; Saito, T.; Tsuge, K.; Ashida, H.; Kugimiya, W.; Inouye, K. Functional properties of soy protein hydrolysates obtained by selective proteolysis. LWT Food Sci. Technol. 2005, 38, 255-261.

98. Mahmoud, M.I. Physicochemical and functional properties of protein hydrolysates in nutritional products. J. Food Sci. 1994, 59, 89-95.

99. Chan, W.M.; Ma, C.Y. Acid modification of proteins from soymilk residue (okara). Food Res. Int. 1999, 32, 119-127.

100. Barca, A.; Ruiz-Salazar, R.; Jara-Marini, M. Enzymatic hydrolysis and synthesis of soy protein to improve its amino acid composition and functional properties. J. Food Sci. 2000, 65, 246-253.

101. Achouri, A.; Zhang, W.; Shiying, X. Enzymatic hydrolysis of soy protein isolate and effect of succinylation on the functional properties of resulting protein hydrolysates. Food Res. Int. 1999, 31, 617-623.

102. Kong, X.; Zhou, H.; Qian, H. Enzymatic preparation and functional properties of wheat gluten hydrolysates. Food Chem. 2007, 101, 615-620. 
103. German, J.B.; O’Neill, T.E.; Kinsella, J.E. Film forming and foaming behavior of food proteins. J. Am. Oil Chem. Soc. 1985, 62, 1358-1366.

104. Zhang, H.J.; Zhang, H.; Wang, L.; Guo, X.N. Preparation and functional properties of rice bran proteins from heat-stabilized defatted rice bran. Food Res. Int. 2010, 47, 359-363.

105. Yalcin, E.; Celik, S.; Ibanoglu, E. Foaming properties of barley protein isolates and hydrolysates. Eur. Food Res. Technol. 2008, 226, 967-974.

106. Harper, W.; Boer, R.; Jelen, P.; Puhan, Z. Functional properties of whey protein concentrates and their relationship to ultrafiltration. In New Applications of Membrane Processes, International Dairy Federation Special Issue 9201; International Dairy Federation: Brussels, Belgium, 1992; pp. 77-108.

107. Babiker, E.E. Effect of transglutaminase treatment on the functional properties of native and chymotrypsin-digested soy protein. Food Chem. 2000, 70, 139-145.

108. Sakamoto, H.; Kumazawa, Y.; Toiguchi, S.; Seguro, K.; Soeda, T.; Motoki, M. Gel strength enhancement by addition of microbial transglutaminase during onshore surimi manufacture. $J$. Food Sci. 2006, 60, 300-304.

109. Fan, J.; Saito, M.; Yanyan, Z.; Szesze, T.; Wang, L.; Tatusmi, E.; Li, L. Gel-forming ability and radical-scavenging activity of soy protein hydrolysate treated with transglutaminase. J. Food Sci. 2005, 70, C87-C92.

110. Sanchez, A.C.; Burgos, J. Factors affecting the gelation properties of hydrolyzed sunflower proteins. J. Food Sci. 1997, 62, 284-288.

111. Léger, L.W.; Arntfield, S.D. Thermal gelation of the $12 \mathrm{~S}$ canola globulin. J. Am. Oil Chem. Soc. 1993, 70, 853-861.

112. Uruakpa, F.O.; Arntfield, S. Emulsifying characteristics of commercial canola protein-hydrocolloid systems. Food Res. Int. 2005, 38, 659-672.

113. Food and Drug Administration. Available online: http://www.fda.gov/Food/FoodIngredients Packaging/GenerallyRecognizedasSafeGRAS/default.html (accessed on 17 August 2012).

114. Commission of the European Communities. Available online: http://ec.europa.eu/food/food/ biotechnology/novelfood/index_en.html (accessed on 17 August 2012).

115. Halken, S.; Host, A.; Hansen, L.G.; Østerballe, O. Safety of a new, ultra filtrated whey hydrolysate formula in children with cow milk allergy: A clinical investigation. Pediatr. Allergy Immun. 1993, 4, 53-59.

116. Szajewska, H.; Albrecht, P.; Stoinska, B.; Prochowska, A.; Gawecka, A.; Laskowska-Klita, T. Extensive and partial protein hydrolysate preterm formulas: The effect on growth rate, protein metabolism indices, and plasma amino acid concentrations. J. Pediatr. Gastr. Nutr. 2001, 32, 303-309.

117. Decsi, T.; Veitl, V.; Szász, M.; Pinter, Z.; Mehes, K. Plasma amino acid concentrations in healthy, full-term infants fed hydrolysate infant formula. J. Pediatr. Gastr. Nutr. 1996, 22, 62-67.

118. Lynch, B.; Simon, R.; van Otterdijk, F.; Emmen, H.; Giuseppin, M.; Kemme-Kroonsberg, C. Subchronic toxicity evaluation of potato protein isolates. Food Chem. Toxicol. 2012, 50, 373-384. 
119. Mejia, L.A.; Korgaonkar, C.K.; Schweizer, M.; Chengelis, C.; Marit, G.; Ziemer, E.; Grabiel, R.; Empie, M. A 13-week sub-chronic dietary toxicity study of a cruciferin-rich canola protein isolate in rats. Food Chem. Toxicol. 2009, 47, 2645-2654.

120. Sarmadi, B.H.; Ismail, A. Antioxidative peptides from food proteins: A review. Peptides 2010, 31, 1949-1956.

121. Moure, A.; Domínguez, H.; Parajó, J.C. Fractionation and enzymatic hydrolysis of soluble protein present in waste liquors from soy processing. J. Agric. Food Chem. 2005, 53, 7600-7608.

122. Hartmann, R.; Wal, J.M.; Bernard, H.; Pentzien, A.K. Cytotoxic and allergenic potential of bioactive proteins and peptides. Curr. Pharm. Design 2007, 13, 897-920.

(C) 2013 by the authors; licensee MDPI, Basel, Switzerland. This article is an open access article distributed under the terms and conditions of the Creative Commons Attribution license (http://creativecommons.org/licenses/by/3.0/). 